\title{
Process Parameter Estimation of Biodiesel Production from Waste Frying Oil (Vegetable and Palm oil) using Homogeneous Catalyst
}

\author{
Aworanti OA, Ajani AO*, Agarry SE \\ Biochemical Engineering and Biotechnology Laboratory, Department of Chemical Engineering, Ladoke Akintola University of Technology, P. M. B. 4000, \\ Ogbomoso, Nigeria
}

\begin{abstract}
Biodiesel from waste frying oil is an effective alternative fuel for conventional diesel and can be directly used as fuel in a diesel engine without any modifications to the engine. It has many positives like high biodegradability, reduction in greenhouse gas emissions, non-sulfur emissions, non-particulate matter pollutants, low toxicity, and excellent lubricity and is obtained from renewable source like vegetable oils, animal fat, etc. The major objectives of this work were to produce and compare the biodiesel yield from Waste Frying Vegetable Oil (WFVO) and Waste Frying Palm Oil (WFPO) using transesterification process. The physicochemical characterization of the biodiesel, as well as the effects of process variables on biodiesel yield, were evaluated. Also, optimum levels of process conditions for optimum production of biodiesel were determined. The WFVO and WFPO with methanol and catalyst were heated in a hot plate-magnetic stirrer at a temperature of $60^{\circ} \mathrm{C}$ and operated at $300 \mathrm{rpm}$. Potassium hydroxide $(\mathrm{KOH})$ was used as catalyst. The one-factor-at-a-time method was used to select the optimum levels of process variable that gives high biodiesel yield. The results showed that the physicochemical characteristics (acid value, free fatty acid, density, kinematic viscosity, pour point and flash point) of the biodiesel obtained from WFVO and WFPO were within the standard value of EN14214 and ASTMD-6751.From the results, the possible optimum conditions of the process variables for transesterification process using $\mathrm{KOH}$ catalyst were found to be as follows: reaction time of 90 min, methanol to oil molar ratio of $12: 1$ and the catalyst loading of $1.5 \mathrm{wt} \%$. At these optimum conditions, the optimum yield of biodiesel obtained from transesterification of WFVO and WFPO were found to be $97 \%$ and $90 \%$, respectively. Thus, in comparison, the transesterification of WFVO resulted in higher biodiesel yield than WFPO. Conclusively, both WFVO and WFPO has good potential to be used for bio-diesel production.
\end{abstract}

Keywords: Biodiesel; Waste frying oil (WFO); Transesterification; Catalyst (KOH); Methanol

\section{INTRODUCTION}

The demand for energy is increasing every day, due to an increase in population growth, industrialization and price of crude petroleum. Availability of conventional energies will be limited in the near future, due to oil depletion [1]. The production process of fossil fuel has led to global climate change, environmental degradation, human health problems and emission of greenhouse gas, as a result of all these problems constituted by production process of fossil fuel, requires to search and provide alternative energy, particularly renewable energy for the world [2]. The renewable energy that can be used to substitute petroleum-derived fuels is biofuel (Biogas and Biodiesel), solar energy, and producer gas, hydrothermal and geothermal $[3,4]$. Biodiesel has been considered as one of alternative fuel as it is a clean renewable fuel, a carbon monoxide emission reducer, non-toxic, biodegradable, and environmentally friendly fuel $[5,6]$. Biodiesel has a good fuel properties such as lower emission of carbon dioxide, high flash point, high cetane number, and good lubrication and it has almost the same characteristics with conventional diesel fuel characteristics (physical and chemical characteristics) therefore it can be used without mixing with petroleum-derived diesel [7-9]. Biodiesel is obtained from any oil or animal fat by transesterification process. Transesterification is a reaction which occurs between lipid and alcohol in the presence of catalyst to form esters (biodiesel) and by-product (glycerol) at a particular temperature and reaction time, also it can be defined as the process which involves the reaction alkyl-alcohol with a long chain esters in the presence of a catalyst to give mono-alkylesthers and glycerol [10-12]. The quality and quantity of biodiesel fuels depend on the types of raw materials (edible oil, non-edible oil,

Correspondence to: Ajani AO, Biochemical Engineering and Biotechnology Laboratory, Department of Chemical Engineering, Ladoke Akintola University of Technology, P. M. B. 4000, Ogbomoso, Nigeria, E-mail: aoajani@lautech.edu.ng

Received: June 20, 2019; Accepted: August 23, 2019; Published: September 03, 2019

Citation: Aworanti OA, Ajani AO, Agarry SE (2019) Process Parameter Estimation of Biodiesel Production from Waste Frying Oil (Vegetable and Palm oil) using Homogeneous Catalyst. J Food Process Technol 10:811. doi: 10.35248/2157-7110.19.10.811.

Copyright: (C2019 Aworanti OA, et al. This is an open-access article distributed under the terms of the Creative Commons Attribution License, which permits unrestricted use, distribution, and reproduction in any medium, provided the original author and source are credited. 
and fat), types of chemical (catalyst and methanol), operating condition, free fatty acid and alcohol to oil ratio [6,13]. Types of catalyst used for transesterification reaction in biodiesel production are homogeneous and heterogeneous catalysts, the homogeneous catalysts are classified into two such as acid and base catalysts while the heterogeneous are classified into three such as acid, base, and enzymatic catalysts, the rate of reaction for base-catalyzed transesterification is higher and produce high amount of biodiesel at reduced reaction time than that catalyzed with acidic catalyst, while enzyme catalyst is a good catalyst for transesterification due to it moderate temperature and high yield but it is expensive, therefore the preferred process for biodiesel production is homogeneous alkaline transesterification because the catalyst is faster and cheaper than other catalysts $[2,14,15]$. Sodium hydroxide and potassium hydroxide are the most used homogenous alkaline catalyst, these catalysts have high conversion at mild conditions and reduced reaction time and the advantages of homogeneous catalysts over heterogeneous catalysts are less corrosive, quantity of alcohol required is small, and not required sophisticated reactors [16]. Biodiesel fuel is produced from different edible and nonedible oil such as groundnut oil, palm oil, coconut oil, soybean oil, sunflower oil, castor oil, and rapeseed oil and the non-edible oil are waste cooking oil, oil extracted from waste crops etc. [17]. It is reported that alkali catalyst is sensitive to free fatty acid in feedstock used for biodiesel production and thus oil such as (Pure vegetable oil) with less than $1 \mathrm{wt} \%$ free fatty acid is required as the feedstocks, para venture the oil selected for the production of biodiesel contain high free fatty acid, an esterification process must be applied in order to eliminate or reduce the free fatty acid before proceeding to the transesterification process [18-21]. It is observed that the cost of biodiesel production using pure refined oil as feedstock is more expensive than petroleum-derived diesel and this is due to the high cost of the refined oil used as feedstocks [17,22,23].The use of waste frying oil (vegetable and palm oil) as feedstock to replace refined vegetable oil in biodiesel production is an alternative way to reduce the feedstock cost and also using the waste oil will solve the problem of waste disposal in the environmental [24-26]. Waste frying oil (Vegetable and palm oil) is defined as used frying oil (Vegetable and palm oil) obtained from frying process. During the frying process, the triglyceride in the refined vegetable and palm oil) break down to form diglycerides, monoglycerides and Free Fatty Acid (FFAs), the waste frying oil(Vegetable and palm oil) compose of these compounds formed during the frying process [27]. The compounds formed during this frying process increase molecular mass of the oil but reduce the volatility of the waste oil $[6,28]$. The properties of the waste frying oil are different from the refined oil, this is due to the chemical reactions during the frying process which include oxidation, hydrolysis, polymerization and material transfer that occurs between the food and oil (Vegetable and palm oil) [27]. Waste frying oil (Vegetable and palm oil) has a higher proportion of saturated fatty acids and renewability of better oxidation stability $[6,29,30]$. According to the ASTM standard, the density, viscosity, acid value, and free fatty acid of waste frying vegetable oil should range between $896-950 \mathrm{~kg} / \mathrm{m}^{3}, 29-40 \mathrm{cst}, 1.5-2 \mathrm{mg}$ of $\mathrm{KOH} / \mathrm{g}$ of oil and $0.1-0.25 \%$ respectively $[6,31]$. While for waste cooking palm oil, the density, viscosity, acid value, and free fatty acid of waste cooking vegetable oil range between $912-916 \mathrm{~kg} / \mathrm{m}^{3}, 133.33-137.53$ $\mathrm{mm}^{2} / \mathrm{s}, 0.2-0.824 \mathrm{mg}$ of $\mathrm{KOH} / \mathrm{g}$ of oil and $0.1-0.412 \%$ respectively $[32,33]$. Many research work has been done on how to reduce the high cost of production and increase the quantity and quality of biodiesel fuel from waste frying vegetable oil and waste frying palm oil using homogeneous catalyst [27,33-37]. However they have not worked toward determination of possible optimum level of process variables for statistical optimization. The aim of this paper is to investigate the potential use of WFVO and WFPO as feedstock for biodiesel production. The effects of catalyst loading, methanol to oil ratio and reaction time on biodiesel yield were evaluated. Also optimum levels of process conditions for optimum production of biodiesel were determined.

\section{MATERIALS AND METHODS}

\section{Sample collection and feedstock preparation}

Waste Frying Vegetable Oil (WFVO) and Waste Frying Palm Oil (WFPO) were collected from various restaurants in Ogbomosho, Oyo State, Nigeria. Methanol, sulphuric acid, propanol, potassium oxide, and phenolphthalein were obtained from a chemical store in Ibadan, Oyo State, Nigeria. A round bottom flask was used as a reactor and magnetic stirrer with hot plate was used as a stirring and heating medium. The waste frying oil (vegetable oil and palm oil) were heated at $70^{\circ} \mathrm{C}$, thereafter the hot wastes frying oil were filtered using filter paper in order to remove its impurities, suspended particles and inorganic materials present in the waste oil. The waste oil was filtered to avoid impairment of oil quality causing reduction in the productivity of the transesterification reaction and also to avoid generation of undesirable by-products that will hurt the final product [38]. The wastes frying oil used for this research work is shown in Figure 1.

\section{Chemical characterization of the waste frying oil}

The chemical characterization of the waste frying oil (vegetable oil and palm oil) and biodiesel produced were analyzed chemically according to the ASTM standards. Properties analyzed were density, viscosity, acid index, iodine index, saponification value, waste content (\%), free fatty acid (\%), flash point and pour point F (Figure 2).

\section{Determination of density and dynamic of waste frying oil} and biodiesel

The density measurement was carried out according to ASTM standards D-5. The density of waste frying oil and biodiesel at $15^{\circ} \mathrm{C}$ were determined by gravimetric analysis, $25 \mathrm{ml}$ waste frying oil was measured with a glass cylinder and the mass of the oil was determined by electronic scale. The density was calculated using equation (1).

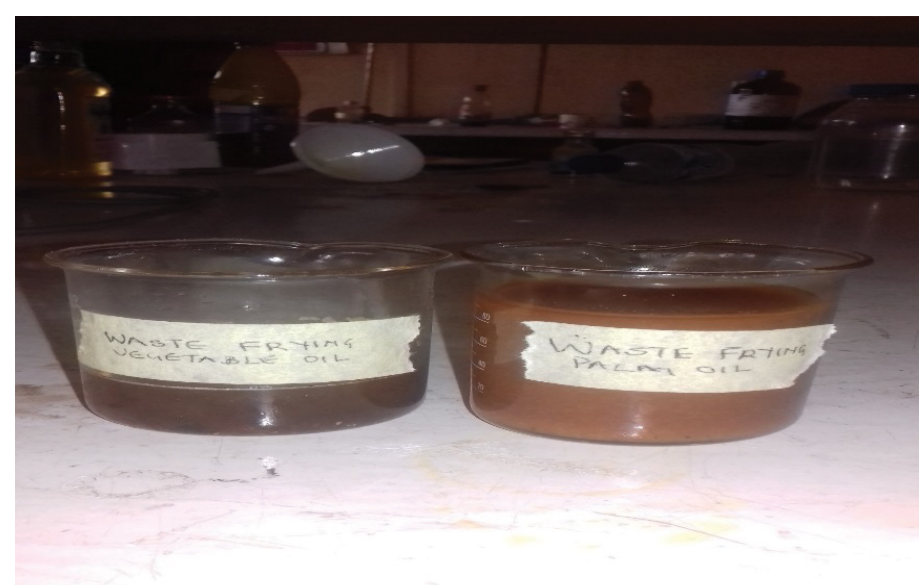

Figure 1: Sample of wastes frying oil. 


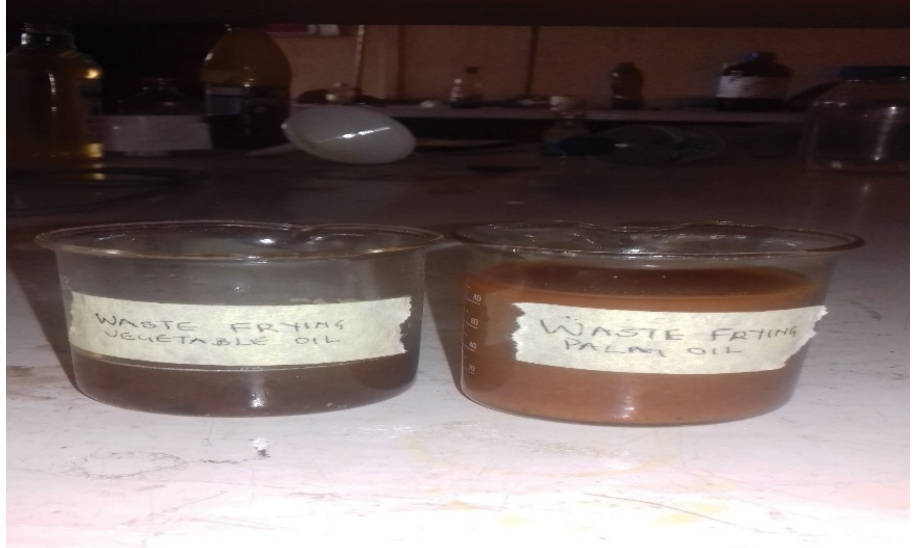

Figure 2: Free fatty acid titration.

$\rho=\frac{m}{v}$

$m(\mathrm{~g})$ is the weight of the sample; $v\left(\mathrm{~cm}^{3}\right)$ volume of the sample.

Determination of viscosity of waste frying oil and biodiesel

The viscosity measurement was carried out according to ASTMD-445. The viscosity of waste frying oil and biodiesel were measured by a falling ball viscometer. The falling-ball viscometer was used to measure the viscosity of liquid by measuring the time required for a ball to fall under gravity through a sample-filled tube that is inclined at an angle. The average time of ten testes were taken in this experiment. The viscosity and kinematic viscosity can be determined by equation ( $2 a$ and $(2 b)$.

$\eta=\mathrm{k} \times \mathrm{t}\left(\rho_{\text {ball }}-\rho_{\text {medium }}\right)$

$v=\frac{\eta}{\rho}$

Where, $\eta$ is the dynamic viscosity $(\mathrm{g} / \mathrm{cm} . \mathrm{s})$

$v$ is the kinematic viscosity $(\mathrm{g} / \mathrm{cm} . \mathrm{s})$

$k$ is the geometrical constant of the ball $\left(\mathrm{m}^{2}\right)$

$\mathrm{t}$ is the fall time through the tube $(\mathrm{s})$

$\rho_{\text {ball }}$ is the density of the ball $\left(\mathrm{g} / \mathrm{cm}^{3}\right)$ and

$\rho_{\text {medium is }}$ the density of the medium $\left(\mathrm{g} / \mathrm{cm}^{3}\right), \rho$ is the density of the sample $\left(\mathrm{g} / \mathrm{cm}^{3}\right)$

\section{Determination of refractive index of waste frying oil and biodiesel}

The refractive index of a medium is a measure of how much the velocity of a wave is reduced inside that medium. In these experiments, the Abbe refractometer was used to measure the refractive index. The light ray pitched on the interphase of phases then it was refracted. The impact angles, rebound, and the refraction were measured between a ray running perpendicular to the phase interface. Ray break is a result of differences in the speed of light in both phases. Refractive index is the ratio of the speed of light in phases, the light passes through. Its principle is the detection of limit angle fracture $\left(\beta_{\max }\right)$, which is the maximum possible angle fracture where the angle of impact is close to $90^{\circ}$.

\section{Determination of saponification value of waste frying oil} and biodiesel

The saponification value was determined according to ASTM standards D-5558. The saponification value was obtained by washing $2 \mathrm{~g}$ of oil into an excess alkaline solution of potassium hydroxide and then titrating the excess alkaline solution mixed with oil with $0.5 \mathrm{~N}$ hydrochloric acid. The saponification valve was calculated based on equation 3 below.

$\mathrm{SV}=\frac{3 \times 56.1 \times 1000}{(\mathrm{MMW} \times 3)+92.09-(3 \times 18)}$

where:

$\mathrm{S} . \mathrm{V}$. is saponification value defined as $\mathrm{mg} \mathrm{KOH}$ per $\mathrm{g}$ of sample

MMV is mean molecular weight

3 is the number of fatty acids per triacylglycerols

56.1 is the molecular mass of $\mathrm{KOH}(\mathrm{g} / \mathrm{mol})$

1000 is the conversion of units $(\mathrm{mg} / \mathrm{g})$

92.09 is a molecular mass of glycerol $(\mathrm{g} / \mathrm{mol}), 18$ is molecular mass of water $(\mathrm{g} / \mathrm{mol})$

\section{Determination of acid value of waste frying oil and biodiesel}

The acid value was determined according to ASTM-D 1980. The acid value is the number of milligrams of $\mathrm{KOH}$ required to neutralize all acid in $1 \mathrm{~g}$ of the sample. The acid value was determined by titration of the sample (oil or biodiesel) dissolved in the mixture of ethanol-toluene with a standardized titration solution of $\mathrm{KOH}$. In this method, a weighed amount of the sample (oil or biodiesel) was added into a flask and it was dissolved in an ethanol-toluene mixture; phenolphthalein was added as an indicator. $\mathrm{KOH}$ was used as titrant solution. The titration process was stopped when the solution turned into pink color. The acid value (AV) was calculated using the equation below:

$\mathrm{AV}\left(\frac{\mathrm{mg} \mathrm{KOH}}{\mathrm{g}}\right)=\frac{56.1 \times \mathrm{C}_{\mathrm{KOH}} \times \mathrm{V}_{\mathrm{KOH}}}{\mathrm{m}}$

Where: 56.1 is the molecular weight of the solution employed for titration $(\mathrm{g} / \mathrm{mol})$

$\mathrm{V}_{\mathrm{KOH}}$ is the consumption during titration (ml)

$\mathrm{C}_{\mathrm{KOH}}(\mathrm{mol} / \mathrm{1})$ is the concentration of the titration $\mathrm{KOH}$ solution; $\mathrm{m}$ is the weight $(\mathrm{g})$ of the analyzed sample

\section{Determination of iodine number of waste frying oil and biodiesel}

This was determined according to the ASTM standard-5554. The iodine value was obtained by weighing $0.5 \mathrm{~g}$ waste frying oil and pour into Erlenmeyer flask. $10 \mathrm{ml}$ of chloroform solution and $25 \mathrm{ml}$ of Hanus solution (Iodine-Bromide Reagent) were added, shaken until all oil were well blended and kept in a dark room for 30 minutes. $10 \mathrm{ml}$ of $15 \% \mathrm{KI}$ solution was added. Titration was done with a solution of $0.1 \mathrm{~N} \mathrm{Na}_{2} \mathrm{~S}_{2} \mathrm{O}_{3}$ and the indicator used was $1 \%$ starch. The titration was stopped when a clear solution was obtained.

Iod Number $=\frac{(b-a) \times \mathrm{Na}_{2} \mathrm{~S}_{2} \mathrm{O}_{3} \times 12.69}{\mathrm{~g}}$ 


\section{Where:}

$a=N u m b e r$ of $m l$ of solution for the titration of the sample

$\mathrm{b}=$ Number of $\mathrm{ml}$ of solution for blank titration

\section{Determination of free fatty acid of waste frying oil}

The free fatty acid of waste frying oil was done according to the procedure reported by Syviengkham [39]. The free fatty acid was determined by titration of the sample (oil) dissolved in the mixture of propanol-phenolphthalein indicator with a standardized titration solution of $\mathrm{KOH}$. In this method, $5 \mathrm{~g}$ of oil was dissolved in $25 \mathrm{ml}$ of propanol then 5 drops of phenolphthalein indicator was added to the oil-propanol solution, thereafter the oil-propanol solution with phenolphthalein indicator was titrated by $0.1 \mathrm{~N}$ $\mathrm{KOH}$ solution until the color of the solution turns to pink color. The Free Fatty Acid (FFA) was calculated using the equation below:

$\% \mathrm{FFA}=\frac{\mathrm{V} \times \mathrm{M} \times \mathrm{N}}{\mathrm{m} \times 10}$

$\mathrm{V}=$ Number of $\mathrm{KOH}$ solution $(\mathrm{ml})$

$\mathrm{M}=$ Molecular weight of oleic acid ( $\mathrm{g} / \mathrm{mole})$

$\mathrm{N}=$ Normality number of $\mathrm{KOH}(\mathrm{g} / \mathrm{L})$

$\mathrm{m}=$ Weight of waste frying oil $(\mathrm{g})$

\section{Determination of pour and flash-points of biodiesel}

The pour and flash-points were determined according to the ASTM standard D97, D25100-8 ad D56, respectively.

\section{Determination of the amount of methanol to oil ratio use for the process}

The molecular weight of the oil was determined using the equation

(7) below:

$\mathrm{M}=\frac{56.1 \times 1000 \times 3}{\mathrm{SV}-\mathrm{AV}}$

$\mathrm{SV}=$ Saponification Value

$\mathrm{AV}=\mathrm{Acid}$ Value

$\mathrm{M}=$ Molecular weight of the oil

Thereafter the amount of methanol was determined by using Equation (8)

$\mathrm{M}=\frac{\mathrm{O} \times \mathrm{b} \times \mathrm{MWM}}{\mathrm{a} \times \mathrm{MWO}}$

$\mathrm{O}=$ Amount of oil

$\mathrm{M}=$ Amount of methanol

$\mathrm{MWO}=$ Molecular weight of oil

MWM=Molecular weight of methanol

$\mathrm{a}=$ molar ratio of oil

$b=$ molar ratio of methanol

\section{Experimental procedure}

Deacidification of waste frying oil by esterification reaction: The esterification reaction was done according to the procedure reported by Ridha et al. [17]. $100 \mathrm{ml}$ of waste frying oil (WFVO and WFPO) were measure and heated at $60^{\circ} \mathrm{C}$, then sulphuric acid
$(0.14 \mathrm{ml})$ and methanol $(55 \mathrm{ml})$ were added to the waste frying oil, the mixture was poured into around bottom flasks and then stirred with magnetic stirrer at $800 \mathrm{rpm}$ for $60 \mathrm{~min}$ thereafter the mixture was allowed to settle in a separation funnel for $2 \mathrm{hr}$ in order to achieve 2 distinct liquid phases (water at the top and preheated oil at the bottom) (Figure 3).

\section{Experimental design: Transesterification of treated waste frying oil}

The transesterification reaction for the production of biodiesel from treated waste frying oil (WFVO and WFPO) was carried out in accordance with the procedure of Aworanti et al. [2]. Onefactor-at-a time (OFAT) approach was used to evaluate the possible optimum level of the operating parameters that can be used for the production of maximum biodiesel fuel yield. The ranges of the operating parameters used are stated in Table 1. Different amount of methanol and catalyst as shown in Table 1 were weighed and mixed vigorously with magnetic stirrer in order for the catalyst to be dissolved and form potassium methoxide solution. Constant volume of pretreated waste frying oil $(100 \mathrm{ml})$ in a round bottom flask was heated to $60^{\circ} \mathrm{C}$, then the potassium methoxide solution was poured gently into the heated waste frying oil (WFVO and WFPO). The entire mixture was stirred with hot plate magnetic stirrer at $300 \mathrm{rpm}$ and the temperature was maintained at $60^{\circ} \mathrm{C}$. The reaction time for the process were also varied and this are shown in the Table 1. After the process, the mixture was poured into a separating funnel and kept for 24 hours so as to separate the glycerin from the biodiesel. The separation segment are glycerol layer at the bottom and biodiesel layer at the top. Thereafter, the physicochemical properties of biodiesel derived from the transesterification of WFVO and WFPO were determined and compared with European norms biodiesel. The apparatus set-up for the biodiesel production are shown in Figures 4-6. The samples of biodiesel produced are shown in Figure 7. The biodiesel yield of the transesterification process was calculated using Equation (9) (Figure 2).

Biodiesel yield $(\%)=\frac{\text { MBP }}{\text { MWFO Used }} \times 100$

MBP: Volume of biodiesel produced (ml); MWFO: Volume of

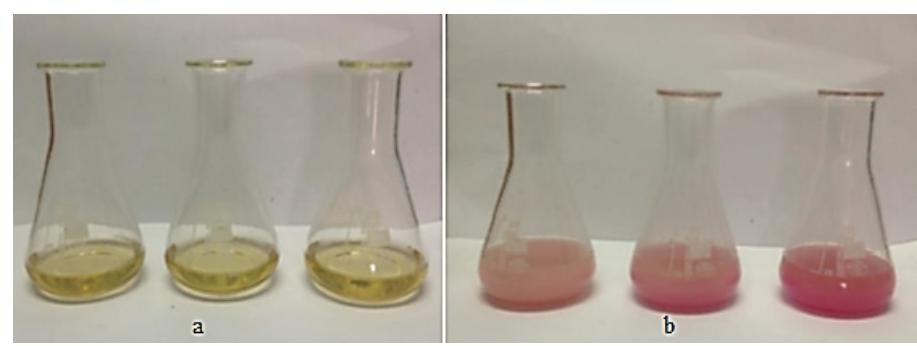

Figure 3: (a) Color comparison before FFA titration; (b) Color comparison after FFA titration.

Table 1: Ranges of operating parameters for one-factor-at-a-time (OFAT) analysis.

\begin{tabular}{lllllll}
\hline Factors & \multicolumn{7}{l}{ Ranges } \\
\hline Operating Parameters Units & 1 & 2 & 3 & 4 & 5 \\
\hline Catalyst & wt\% & 0.1 & 0.5 & 1 & 1.5 & 2 \\
\hline Methanol:oil & Ratio & $1: 1$ & $3: 1$ & $6: 1$ & $9: 1$ & $12: 1$ \\
\hline Reaction Time & Mins. & 30 & 60 & 90 & 120 & 150 \\
\hline
\end{tabular}




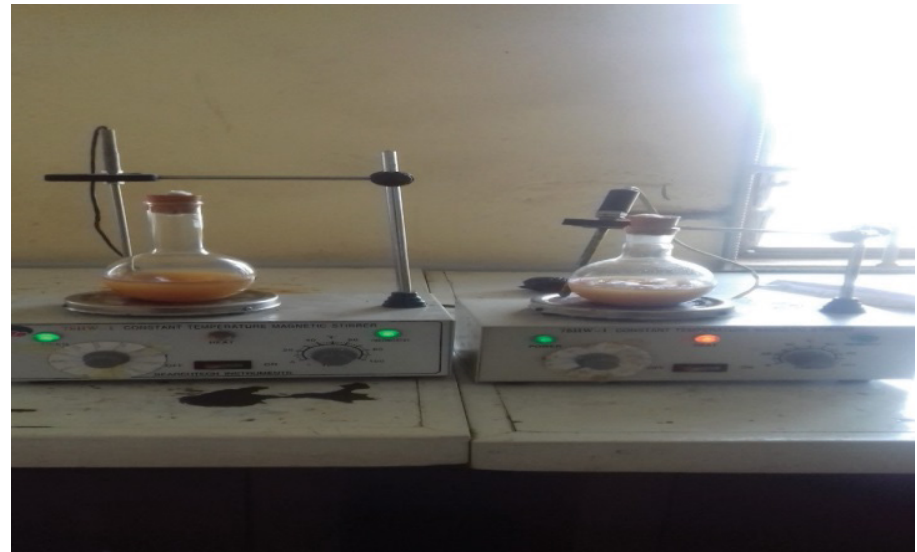

Figure 4: Biodiesel production set-up.

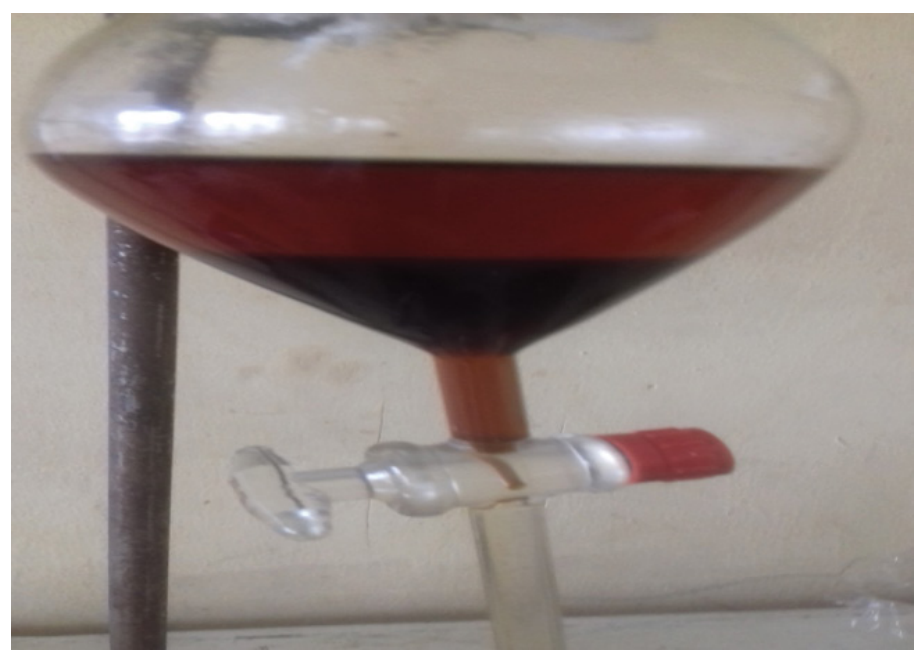

Figure 5: Biodiesel-glycerin separation from waste frying palm oil.

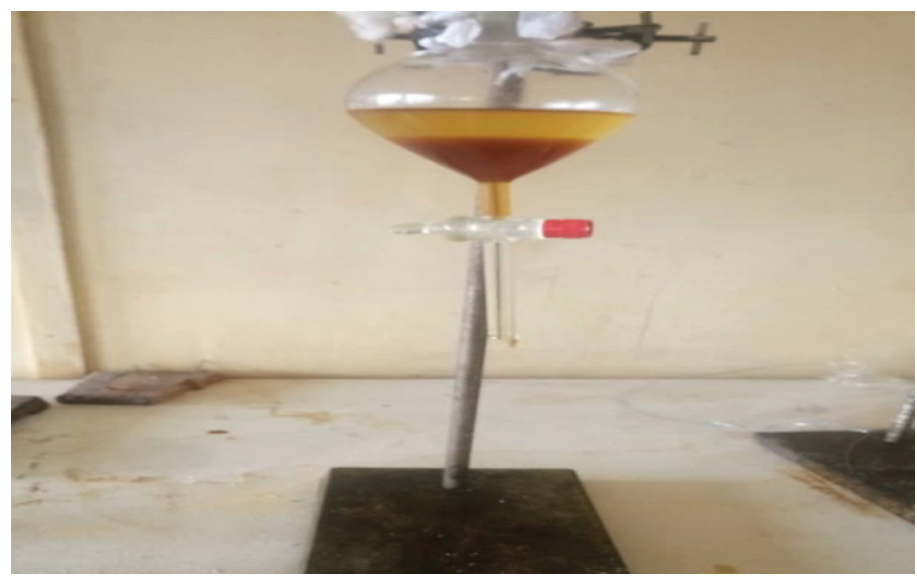

Figure 6: Biodiesel-glycerin separation from waste frying vegetable oil.

\section{RESULTS AND DISCUSSION}

\section{Physicochemical characterization of wastes frying oil used in biodiesel production}

The result of the properties of wastes frying oil analyzed in this study is as presented in Table 2, it was observed that the free fatty acid values of the various samples were more than $2 \%$, which justifies pretreatment (esterification) of the waste frying oil samples in order to reduce the free fatty acids in the wastes oil [40]. This high percentage of Free Fatty Acids (FFAs) in the WFVO and

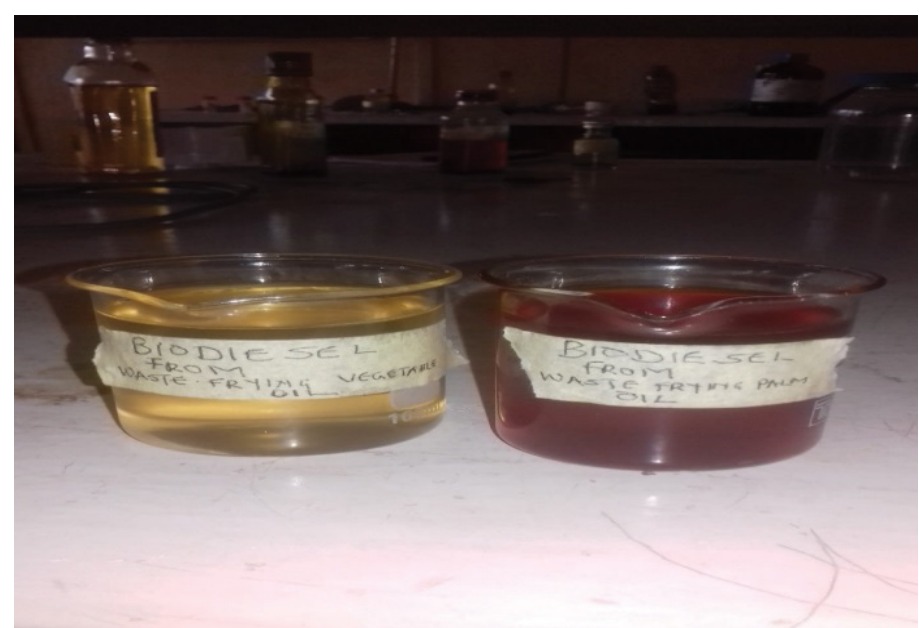

Figure 7: Sample of biodiesel produced from wastes frying oil (WFVO and WFPO).

Table 2: Physico-chemical properties of waste frying oil used for transesterification experiment.

\begin{tabular}{lcc}
\hline Parameters determined & $\begin{array}{c}\text { Waste Frying vegetable } \\
\text { oil }\end{array}$ & $\begin{array}{c}\text { Waste frying palm } \\
\text { oil }\end{array}$ \\
\hline $\begin{array}{l}\text { Viscosity at } 40^{\circ} \mathrm{C} \\
\left(\mathrm{mm}^{2} / \mathrm{s}\right)\end{array}$ & 38.45 & 46.97 \\
\hline Density $\left(\mathrm{kg} / \mathrm{m}^{3}\right)$ & 946 & 908 \\
\hline Flash point $\left({ }^{\circ} \mathrm{C}\right)$ & 310 & 223 \\
\hline Free fatty acid $(\%)$ & 2.5 & 14.25 \\
\hline $\begin{array}{l}\text { Specific gravity at } 15^{\circ} \mathrm{C} \\
\mathrm{g} / \mathrm{cm}^{3}\end{array}$ & 0.9460 & 0.9082 \\
\hline $\begin{array}{l}\text { Acid number } \mathrm{mg} \mathrm{KOH} / \mathrm{g} \\
\text { Refractive index }\end{array}$ & 5 & 28.5 \\
\hline $\begin{array}{l}\text { Iodine value } \mathrm{gI} / 2 / 100 \mathrm{~g} \\
\text { Saponification value } \\
\text { mg KOH/g }\end{array}$ & 1.464 & 1.475 \\
\hline
\end{tabular}

WFPO is caused due to the effect of frying on the properties of WFVO and WFPO, such as temperature and frying time. When the vegetable oil is subjected to thermal stress during frying, its chemical and physical original characteristics completely change. The quantity of heat to fry and quantity of water in the frying oil increases the hydrolysis of triglycerides, therefore it leads to high percentage of Free Fatty Acids (FFAs) in the WFVO and WFPO [41]. The high free fatty acids content in the waste frying vegetable oil and palm oil (2.5\% and $14.25 \%$ ), respectively can result into soap formation in the presence of potassium hydroxide during transesterification reaction of the oil. Studies also show that high FFA reduces catalyst effectiveness and decreases the production yield [42]. Increase in the viscosity and saponification number of WFO compare to refined oil are caused by oxidation and polymerization reactions during frying [43]. Also high content of water in the WFVO is caused by transportation of matter and heat between the frying food and the vegetable oil [44]. Hydrolysis is formed during transesterification reaction, due to the presence of water in the WCO samples, high saponification number and free fatty acid can lead to saponification reactions. Both hydrolysis and saponification reactions cause low biodiesel yield and catalyst consumption [44]. To avoid the saponification reaction, hydrolysis and reduction in catalyst, the oil must be heated at a particular temperature in order to remove the water, then pretreatment of this oil by the esterification reaction with sulfuric acid in the 
presence of methanol was required to reduce the Free Fatty Acids (FFA) to the limit necessary to achieve the transesterification reaction. The saponification number of waste frying vegetable oil and palm oil used for this research work were $181.2 \mathrm{mg} \mathrm{KOH} / \mathrm{g}$ and $175.9 \mathrm{mg} \mathrm{KOH} / \mathrm{g}$, respectively. The saponification number indicates the amount of potassium hydroxide $(\mathrm{KOH})$ needed to saponify (converted to soap) one gram of oil. It was reported in the literature that saponification number for waste frying vegetable oil ranges from (176 to 187$) \mathrm{mg} \mathrm{KOH} / \mathrm{g}$ oil, while for waste frying palm oil ranges from (177 to 200) $\mathrm{mg} \mathrm{KOH/g} \mathrm{[32].} \mathrm{Sánchez} \mathrm{et} \mathrm{al.}$ [45] reported that the saponification number of waste cooking oil was $196.98 \mathrm{mg} \mathrm{KOH} / \mathrm{g}$ oil. The saponification number of waste frying vegetable oil and palm oil used in this work falls within the literature report. The density of waste frying vegetable oil and palm oil used for the transesterification reaction are $946 \mathrm{~kg} / \mathrm{m}^{3}$ and $908 \mathrm{~kg} / \mathrm{m}^{3}$, respectively. The results obtained are within the range reported in the literature $(0.9625 \mathrm{~g} / \mathrm{ml}$ and $0.9772 \mathrm{~g} / \mathrm{ml})$ [46]. Comparing this literature value with the density values of waste frying oil in this research work, we concluded that there is no significance difference with values reported in the literature. The kinematic viscosity value of the waste frying vegetable oil and palm oil are $38.5 \mathrm{~mm}^{2} / \mathrm{s}$ and $46.97 \mathrm{~mm}^{2} / \mathrm{s}$, respectively. Kappe [32] reported the viscosity value of waste cooking oil to be $40 \mathrm{cP}$, which is in the range with the viscosity value of waste frying oil used in this research. Density, specific gravity and kinematic viscosities have been described as one of the most basic and most important properties of fuel because some important performance indicators such as cetane number and heating values are correlated with the parameters [47-49]. Flash point is defined the temperature at which biodiesel burns when in contact with ignition source. Flash point of the waste frying vegetable oil and waste palm oil are $310^{\circ} \mathrm{C}$ and $223^{\circ} \mathrm{C}$ respectively, the acid value of the waste frying vegetable oil and palm oil for this work were $5 \mathrm{mg} \mathrm{KOH} / \mathrm{g}$ and $28.5 \mathrm{mg} \mathrm{KOH} / \mathrm{g}$, respectively. The acid value is one of the most important properties used to determine biodiesel quality and the percentage of free fatty acids contained in each oil [50]. It shows the amount of corrosive acid as well as oxidation products present in the oil. From literature the acid value should be lower than $0.50 \mathrm{mg} \mathrm{KOH} / \mathrm{g}$ specified by ASTM standard [51]. According to Meher et al. [52] the acid value of waste cooking oil for transesterification reaction must be in the range of $(0.2$ to 0.824$) \mathrm{mg} \mathrm{KOH} / \mathrm{g}$. Comparing this result with the literature it shows that the oil used in this research work has a very high acid value and it is inferred that it has been over-used. Therefore the oil must be pretreated in order to reduce free fatty acids. The iodine value of waste frying vegetable oil and palm oil were 2.74 and 1.56 , respectively. The iodine value indicates the amount of this compound which can absorb the vegetable oil and palm oil in unsaturated bonds, that is, the larger the index value the greater adsorption on the double bonds present in the oil [53]. From the literature the iodine value of waste cooking oil ranges between $(60-70) \mathrm{mg} / 100 \mathrm{~g}$ [32], the iodine values obtained in this work were very low which indicate low adsorption rate on the double bonds and also the compound that absorb the vegetable oil and palm oil in unsaturated bonds is low.

\section{Physical property of biodiesel produced}

The value of fatty acid number of biodiesel product: The result of free fatty acid of biodiesel production from waste frying vegetable oil and palm oil are $0.13 \mathrm{mg} / \mathrm{KOH}$ and $0.29 \mathrm{mg} / \mathrm{KOH}$ respectively. According to the data of ASTMD-6751, the maximum value of free fatty acid in biodiesel is $0.8 \mathrm{mg} / \mathrm{KOH}$. The result shows that the biodiesel product has a value that is in accordance with the standard. The acid value is one of the most important properties for biodiesel quality check. High acid value can cause sediment in the fuel system and corrosion of the media. The higher the acid value the lower the quality of biodiesel $[1,54]$.

Iodine value of biodiesel product: The result of iodine number of methyl ester from waste frying vegetable oil and palm oil are $2.210 / 100 \mathrm{~g}$ and $1.4352 / 100 \mathrm{~g}$ respectively. The result of the analysis shows that iodine number in biodiesel from synthesis according to standard biodiesel value determined by SNI $[1,55]$. If the iodine value of biodiesel produced is higher than the standard of 115 $\mathrm{g} / 100 \mathrm{~g}$, it will lead to polymerization and formation of deposits in injector's nozzle and piston rings at the start of combustion.

Density value of biodiesel product: The results of density of transesterification process from waste frying vegetable oil and palm oil are $860 \mathrm{~kg} / \mathrm{m}^{3}$ and $900 \mathrm{~kg} / \mathrm{m}^{3}$ respectively. The results obtained meets the EN14214 and ASTMD-6751 standard. Density provides information on how the fuel will work in diesel engines. High density value indicate some impurities in the biodiesel [54]. The use of high temperature during the transesterification reaction will increase the saponification reaction.

Viscosity value of biodiesel product: The results of viscosity value of biodiesel from waste frying vegetable oil and palm oil are 4.10 $\mathrm{mm}^{2} / \mathrm{s}$ and $6.03 \mathrm{~mm}^{2} / \mathrm{s}$. The result of the analysis falls within the specification range of the ASTM D-6751 standard. Viscosity is defined as fluid resistance to the flow rate of a mm-sized capillary. If the viscosity value is high it will lead to formation of oxidized polymeric compounds and this can lead to the formation of gums and sediments that clog the filters in the engine [56].

Acid value of biodiesel product: Based on results obtained, the acid number from biodiesel produced from waste frying vegetable oil and waste frying palm oil falls within the range of the ASTMD-6751 standard. Acids can be formed when traces of water is presence in the biodiesel which result into hydrolysis of the esters to form alcohol and acids [56]. The acid number increases with an increase in peroxides because the esters first oxidize to form peroxides which then undergo complex reactions, including a split into more reactive aldehydes which further oxidize into acids. Acid number indicates the level of Free Fatty Acids (FFAs) present in biodiesel. Acid value lower than $0.5 \mathrm{mg} \mathrm{KOH} / \mathrm{g}$ is ideal as fuel for vehicle. A high acid value can have a strong solvency effect on rubber seals and hoses in the engine, thereby causing premature failure. It may also be left deposits, which can clog the fuel filter or drop fuel pressure.

Flash point and pour point: Flash point is the temperature at which biodiesel burns when in contact with ignition source. The value of flash point of the biodiesel produced from waste frying vegetable oil and waste frying palm oil were $164^{\circ} \mathrm{C}$ and $129^{\circ} \mathrm{C}$. These values fall within the range of biodiesel flash point standard (ASTM D6751). Pour point has been described as an important parameter for low temperature operation of a fuel also the lowest temperature at which fuel can flow. It is the temperature at which wax becomes visible when the fuel is cooled and it is sufficient to gel the fuel [49]. The value of pour point of the biodiesel produced from waste frying vegetable oil and waste frying palm oil were $-3^{\circ} \mathrm{C}$ and $5^{\circ} \mathrm{C}$. These values fall within the range of biodiesel pour point standard (ASTM D6751). Lastly the appearances of the biodiesel produced was noticed, it was observed that the biodiesel produced from waste frying vegetable oil and waste frying palm oil are of 
different colour. Their colours are yellow and brown respectively (Table 3).

\section{Effect of operating variables on biodiesel yield}

Effect of catalyst loading on biodiesel yield: The biodiesel yields obtained from the transesterification of WFVO and WFPO at different amount of catalyst $(\mathrm{KOH})$, using 9:1 methanol to oil ratio, operated at stirring rate of $300 \mathrm{rpm}$ and temperature of $60^{\circ} \mathrm{C}$ for 90 min are shown in Figure 8. It is observed from the plot that biodiesel yield obtained from WFVO and WFPO increases with increase in catalyst loading up to $1.5 \mathrm{wt} \%$. It could be seen that the yield respectively increases to $86 \%$ and $90 \%$ for WFPO and WFVO when the catalyst loading increased to $1.5 \mathrm{wt} \%$ at $90 \mathrm{~min}$, while the yield decreases to $55 \%$ and $80 \%$ for WFPO and WFVO as the catalyst loading increased above $1.5 \mathrm{wt} \%$. Thus optimum catalyst loading that resulted in optimum biodiesel yield of $86 \%$ and $90 \%$ was found to be $1.5 \mathrm{wt} \%$ for both WFPO and WFVO, respectively. This observation may be due to the fact that, an increase in catalyst amount up to $1.5 \mathrm{wt} \%$ increases the total number of active sites, resulting in an increase in biodiesel conversion [57,58], while an increase in catalyst loading above $1.5 \mathrm{wt} \%$ makes the reactant and catalyst mixture too viscous leading to problems with mixing and poor diffusion of the reactants, thus resulting in a decrease in the biodiesel yield $[31,57,59,60]$. Furthermore, decrease in yield may also be attributed to the fact that the solubility of methanol in oil is low and increasing catalyst loading provides more active sites to adsorb the products consequently, the yield of biodiesel decreases [61]. Also the low biodiesel yield at catalyst loading above $1.5 \mathrm{wt} \%$ may be due to the attainment of mass transfer limitation (rate determining step) between the reactant and catalyst [62] (Figure 8).

Table 3: Properties of biodiesel produced from WFCO and WFPO.

\begin{tabular}{lcccc}
\hline Properties & $\begin{array}{c}\text { WFCO } \\
\text { biodiesel }\end{array}$ & $\begin{array}{c}\text { WFPO } \\
\text { biodiesel }\end{array}$ & EN14214 & $\begin{array}{c}\text { AST- } \\
\text { MD-6751 }\end{array}$ \\
\hline Acid value $\mathrm{mg} \mathrm{KOH} / \mathrm{g}$ & 0.26 & 0.57 & - & $<0.8$ \\
\hline Free fatty acid $(\%)$ & 0.13 & 0.29 & & 0.8 \\
\hline $\begin{array}{l}\text { Density at } 32^{\circ} \mathrm{C}(\mathrm{kg} / \\
\left.\mathrm{m}^{3}\right)\end{array}$ & 863 & 864 & $860-900$ & $875-900$ \\
\hline $\begin{array}{l}\text { Kinematic viscosity at } \\
40^{\circ} \mathrm{C}\left(\mathrm{mm}^{2} / \mathrm{s}\right)\end{array}$ & 4.10 & 6.0 & $3.5-5.0$ & $1.9-6.0$ \\
\hline Pour point $\left({ }^{\circ} \mathrm{C}\right)$ & -3 & 5 & - & -15 to 10 \\
\hline Flash point $\left({ }^{\circ} \mathrm{C}\right)$ & 164 & 129 & - & $>130$ \\
\hline Iodine value $\mathrm{gI} / \mathrm{l} / 100 \mathrm{~g}$ & 2.210 & 1.435 & & \\
\hline Refractive index & 1.44 & 1.45 & & \\
\hline Biodiesl Yield $(\%)$ & 97 & 90 & $>96.5$ & $>96.5$ \\
\hline
\end{tabular}

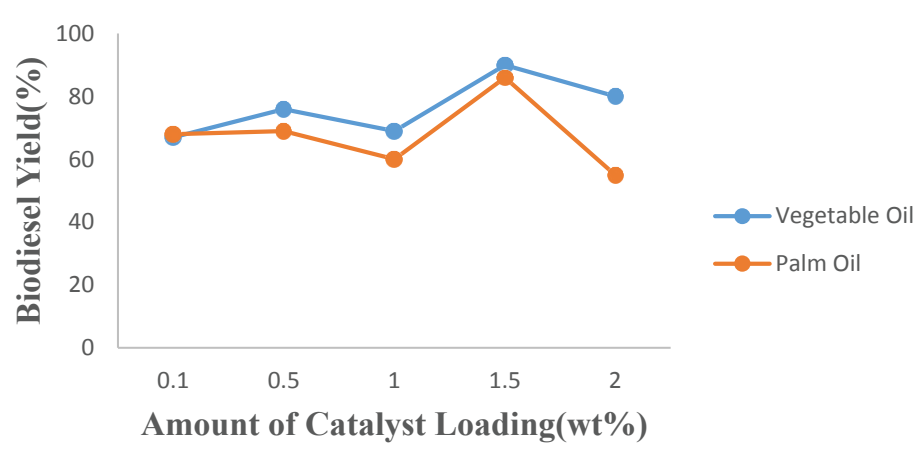

Figure 8: Effect of catalyst loading on the process of transesterification using WFVO and WFPO.
Effect of methanol/oil molar ratio on biodiesel yield: The yields of biodiesel obtained from transesterification of WFVO and WFPO by using different values of molar ratio of oil to methanol are shown in Figure 9. Thus, the optimum methanol to oil ratio was determined by carrying out the transesterification reaction with various methanol to oil ratios (1:1, 3:1, 6:1, 9:1 and 12:1) using a catalyst loading of $1.5 \%$ and a time of $90 \mathrm{~min}$ at temperature $60^{\circ} \mathrm{C}$. It was observed in the plot that, at methanol to oil ratio of 1:1 and 3:1 a high biodiesel yields from both WFPO and WFVO was never achieved, an increase in relation to molar proportion ranging between $6: 1$ to $12: 1$ prompted a substantial increase in biodiesel yields obtained from WPVO and WFVO from $60 \%$ to $90 \%$ and $75 \%$ to $97 \%$ respectively was noticed in the plot. Thus optimum methanol to oil ratio that resulted in optimum biodiesel yields of $90 \%$ and $97 \%$ was obtained was found to be (12:1) for both WFPO and WFVO, respectively. Whereas the biodiesel yields obtained from WFPO and WFVO were deteriorated at methanol to oil ratio of $1: 1$. The methanol to oil ratio is another important factor which affects the biodiesel yields. In order to increase the biodiesel yields and to keep the equilibrium on the right side of the reaction, it is necessary to increase the methanol in the reaction [63]. Hypothetically, every mole of biodiesel is a result of one mole of methanol and 1/3 of a triglyceride mole from the transesterification response. Stoichiometrically, $3 \mathrm{~mol}$ of methanol is required to one mol of glyceride [64].

Effect of reaction time on biodiesel yield: The influence and effect of reaction time on biodiesel yields was examined under the following operating conditions: $1.5 \mathrm{wt} \%$, temperature of $60^{\circ} \mathrm{C}$ and molar ratio of $12: 1$ and the biodiesel yields obtained at different time intervals are shown in Figure 10. The experimental result shows that the biodiesel yields obtained from WFPO and WFVO increases with increase in time up to $90 \mathrm{~min}$, it could be seen that the yields respectively increases to $90 \%$ and $97 \%$ for WFPO and WFVO when the time increased to $90 \mathrm{~min}$, while the yields decreases to $70 \%$ for both WFPO and WFVO as the time increased above $90 \mathrm{~min}$. Thus optimum time that resulted in optimum biodiesel yields of $90 \%$ and $97 \%$ was found to be $90 \mathrm{~min}$ for both WFPO and WFVO, respectively. The yields deteriorated

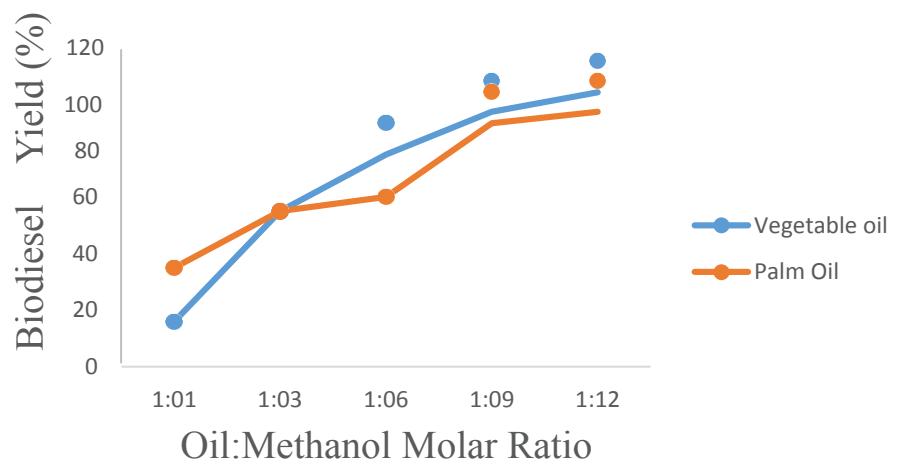

Figure 9: Effect of Methanol/oil molar ratio on the process of transesterification using WFVO and WFPO.

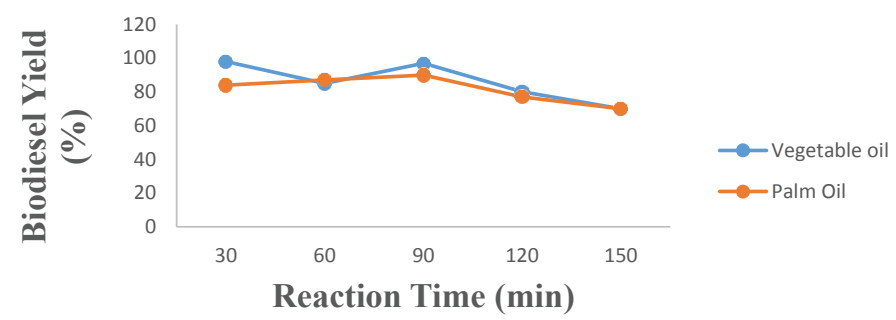

Figure 10: Effect of reaction time on the process of transesterification using WFVO and WFPO. 


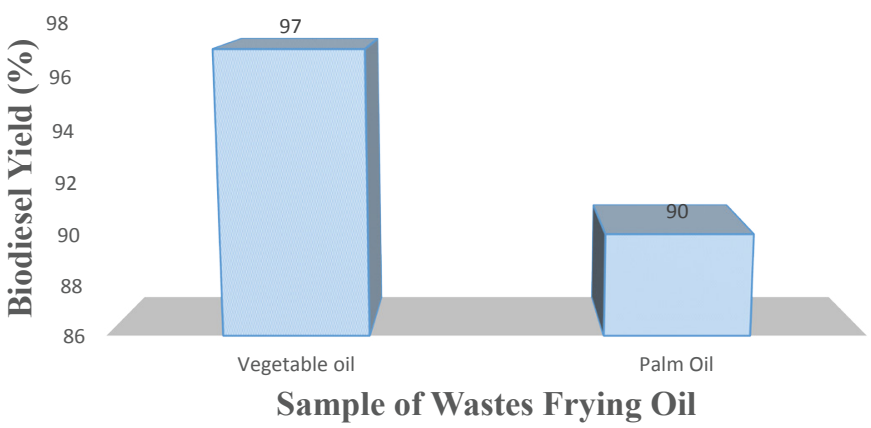

Figure 11: Biodiesel yield from different waste frying oil.

after 90 min because hydrolysis of esters may start to occur with a further increase in the reaction time, which results in more fatty acids forming soap [65]. Additionally, a back reaction may take place after reaching the equilibrium since the reaction is reversible, subsequently decreasing the yield $[29,39,60,66-68]$.

Assessment of optimum biodiesel yield from WFVO and WFPO : Assessment of biodiesel yields obtained from the transesterification of WFVO and WFPO carried out at optimum conditions of 1.5 wt $\%$ catalysts, 1:12 oil to methanol molar ratio, 90 min reaction time and at a temperature $60^{\circ} \mathrm{C}$ is shown in Figure 11. The experimental results reveals that transesterification of WFVO at the above optimum conditions resulted in the optimum yield of 97\% when compared with the transesterification of WFPO which produced an optimum yield of $90 \%$ at the same optimum operating conditions. The reason for this observation may be due to the high value of free fatty acid present in the waste frying palm oil. A Similar observation has been reported by Hossain and Mazen and Ali and Kavita [11,34] who respectively obtained a biodiesel yield of $68.9 \%$ from wastes soybean oil using $0.5 \% \mathrm{KOH}$ as catalyst $94.4 \%$ from wastes cooking oil using 0.4 wt. $\% \mathrm{KOH}$.

\section{CONCLUSION}

The aim of this project was to assess biodiesel yield from two different waste frying oil (vegetable oil and palm oil) and also to determine the optimal reaction conditions on transesterification process. One factor at a time was used to determine the optimal condition that can be used to produce biodiesel from waste frying oil. The optimum conditions for producing biodiesel were: methanol to the oil (12:1), amount of catalyst loading (1.5 wt\%), and reaction time $(150 \mathrm{~min})$. The optimum yield of biodiesel was $97 \%$ obtained from transesterification process of waste frying vegetable oil. Also, increase in the operational parameters (methanol to oil molar ratio, catalyst and reaction time) increased the biodiesel production rate, biodiesel production potential and these subsequently increased the biodiesel yield. Among the two different of waste frying oil used, biodiesel produced from transesterification process of waste frying vegetable oil relatively gave a higher yield of biodiesel when compared with waste frying palm oil. It was found out that important fuel properties biodiesel produced at optimum condition met the biodiesel ASTM standard. Pure biodiesel was determined by ASTM standards to ensure that the following important factors in the fuel production process by transesterification are satisfied: complete transesterification reaction, complete esterification of FFA, removal of glycerol, removal of catalyst and removal of alcohol. Lower viscosity value of the final product is an indication of completion of reaction and removal of heavy glycerol. The product characterization meet the requirements the American Standard (ASTM) for biodiesel fuel.
Waste frying oil is a cost effective and promising feedstock. WF with higher FFA content results is decrease in the overall yield. In this case, esterification is to be done before transesterification. Homogeneous catalysts like $\mathrm{NaOH}$ and $\mathrm{KOH}$ are known for having less reaction time and moderate reaction conditions but oils with high FFA may result in soap formation which reduces the overall yield and the recovery if catalyst is difficult. For carrying transesterification, batch reactors are preferred over continuous because of easy assemblage, maintenance, inexpensive and easy to design. Obtaining higher yield of product depends upon the quality of oil used. The parameters affecting the reaction were identified to be methanol to oil molar ratio, the catalyst used and its amount, reaction time and the reaction temperature.

\section{REFERENCES}

1. Okta S, Ceria S, Risfidian M. Preparation of calcium oxide from cattle bones as catalyst for conversion of waste cooking oil to biodiesel. Sci Technol Indonesia. 2017;2:67-69.

2. Aworanti OA, Agarry SE, Ogunleye OO. Biomethanization of the mixture of cattle manure, pig manure and poultry manure in codigestion with waste peels of pineapple fruit and content of chicken gizzard-Part II: Optimization of process variables. The Open Biotechnol J. 2017;(11):54-71.

3. Dewulf J, Van Langenhove H. Renewables-based technology: sustainability assessment. John wiley and Sons, Ltd. 2006.

4. Rutto H, Enweremadu C. Optimization of production variables of biodiesel using calcium oxide as a heterogeneous catalyst: an optimized process. Materials and processes for energy communicating current research and technological developments.

5. Sani J, Sokoto MA, Tambuwal AD, Garba NA. Effect of $\mathrm{NiO} / \mathrm{SiO}_{2}$ on thermochemical conversion of waste cooking oil to hydrocarbons. Heliyon. 2017;3(5):e00304.

6. Tshizanga Ngoya. A study of biodiesel production from waste vegetable oil using eggshell ash as a heterogeneous catalyst, Thesis of Master of Technology, Chemical Engineering in the Faculty of Engineering at the Cape Peninsula University of Technology. 2015:2.

7. Aworanti OA, Agarry SE, Ajani AO. Statistical optimization of process variables for biodiesel production from waste cooking oil using heterogeneous base catalyst. British Biotechnol J. 2013;3(2):116-132.

8. Bouaida A, Martineza M, Aracil J. Long storage stability of biodiesel from vegetable and used frying oils. Fuel. 2007;86:2596-2602.

9. Canakci M. The potential of restaurant waste lipids as biodiesel feedstocks. Bioresour Technol. 2007;98:183-190.

10. Abdelfatah M, Kiros Y, Abu Elala R. Biodiesel production from waste cooking oil using different heterogeneous catalysts support on alumina. Petrol Petrochem Eng J. 2017;1(6):1-7.

11. Hossain ABMS, Mazen MA. Effects of catalyst types and concentrations on biodiesel production from waste soybean oil biomass as renewable energy and environmental recycling process. Australian J Crop Sci. 2010:550-555.

12. Oji A, Emuraye E. Comparative study of biodiesel produced from waste cooking oil. J Scient Eng Research. 2016;3(5):39-45.

13. Clark WN, Medeiros NJ, Boyd DJ, Snell JR. Biodiesel transesterification kinetics monitored by $\mathrm{pH}$ measurement. Bioresource Technol. 2013;136:771-774.

14. Kouzu M, Hidaba JS. Transesterification of vegetable oil into biodiesel catalysed by $\mathrm{CaO}$ : A review. Fuel. Journal American Oil Soc Chem. 2001;78(2):703-707. 
15. Watanabe Y, Shimada Y, Sugihara A, Tominaga Y. Enzymatic conversion of waste edible oil to biodiesel fuel in a fixedbed bioreactor. JAOCS. 2012;93:1-12.

16. Diego R, José R, Dionisio MR. Production of biodiesel from waste cooking oil and castor oil blends. Chem Eng Transact. 2017;57:679-684.

17. Ridha B, Snoussi Y, Mounir B, Manef A. Waste frying oil with high levels of free fatty acids as one of the prominent sources of biodiesel production. J Mater Environ Sci. 2015;6(4):1178-1185.

18. Ni J, Meunier FC. Esterification of free fatty acids in sunflower oil over solid acid catalysts using batch and fixed bed-reactors. Applied Catalysis A: General. 2007;33:122-130.

19. Simasatitkul L, Ganib R, Arpornwichanop A. Optimal design of biodiesel production process from waste cooking palm oil $20^{\text {th }}$ International Congress of Chemical and Process Engineering CHISA Prague, Czech Republic Procedia Engineering. 2012;42:1292-1301.

20. Turapan S, Cattareya Y, Kamchai N. Esterification of free fatty acids in crude palm oil with sulfated zirconia: Effect of calcination temperature. World Academy of Science, Engineering and Technology. Int J Chem Mol Eng. 2010;4(5):310-314.

21. You Y, Shie J, Chang C, Huang S, Pai C, Yu Y, et al. Economic cost analysis of biodiesel production: case in soybean oil. Energy Fuels. 2007;22:182-189.

22. Atabani AE, Silitonga AS, Badruddina IA, Mahlia TMI, Masjuki HH, Mekhilef S. A comprehensive review on biodiesel as an alternative energy resource and its characteristics. Renew Sustain Energy Rev. 2012;16(4):2070-2093.

23. Dwivedi G, Sharma MP. Impact of antioxidant metals on biodiesel stability-A review. J Mater Environ Sci. 2014;5:1412-1425.

24. Berchmans HJ, Hirata S. Biodiesel production from crude Jatropha curcas L. seed oil with a high content of free fatty acids. Bioresour Technol. 2008;99:1716-1721.

25. Zhang Y, Dube MA, McLean DD, Kates M. Biodiesel production from waste cooking oil: Process design and technological assessment. Bioresour Technol. 2003;1(89):1-16.

26. Goyal P, Sharma MP, Jain S. Optimization of conversion of high free fatty Jatropha curcas oil to biodiesel using response surface methodology. J Mater Environ Sci. 2012;6:1100.

27. Mohammed A, Bhargavi R. Biodiesel production from waste cooking oil. J Chem Pharm Res. 2015;7(12):670-681.

28. Liu X, He H, Wang Y, Zhu S, Ziao X. Transesterification of soybean oil biodiesel using $\mathrm{CaO}$ as solid base catalyst. Fuel. 2009;87:216-221.

29. Agarwala AK, Dhar A, Gupta JG, Woong KII, Choi K, Lee CS, et al. Effect of fuel injection pressure and injection timing of Karanja biodiesel blends on fuel spray, engine performance, emissions and combustion characteristics. Energy Convers Manag. 2015;91:302-314.

30. Sharma YC, Singh B, Upadhyay SN. Advancement in development and characterisation of biodiesel: a review. Fuel. 2008;87:2355-2373.

31. Birla A, Singh B, Upadhyay SN, Sharma YC. Kinetics studies of synthesis of biodiesel from waste frying oil using a heterogeneous catalyst derived from snail shell. Bioresour Technol. 2012;106:95-100.

32. López L, Bocanegra J, Malagón-romero D. Obtención de biodiesel por transesterificación de aceite. Ingeniería y Universidad. 2015;19(1):155-172.

33. Richard A, Dionisio MR, Alexander L. Biodiesel production from waste frying oil and palm oil mixtures. Chem Eng Trans. 2017;57:571-576.

34. Ali M Salleh, Kavita K. Production of bio-diesel from waste cooking oil by using homogeneous catalyst. Int J Chem Sci. 2014,12(3):941-951.

35. Ayoola A, W Stephen I. Investigation on biofuel production using two base catalysts. I J Res Eng Technol. 2014;2(6):99-104.
36. Ebenaza GT, Vinoth E. Biodiesel Production from waste cooking oil. Int J Res Technol Manag. 2015;3(8):448-450.

37. Maurizio C, Sonia C, Silvia C. A pilot-scale study of waste vegetable oil transesterification with alkaline and acidic catalysts. Sci Dir Energy Procedia. 2014;45:198-206.

38. Calero J, Cumplido G, Luna D, Sancho ED, Luna C, Posadillo A, et al. Production of a biofuel that keep the glycerol as a monoglyceride by using supported KF as heterogeneous catalyst. Energies. 2014;7:3764-3780.

39. Syviengkham P. Pretreatment of high free fatty acid Jatropha oil by esterification. Thesis, Master of Science, National University of Laos. National Research Foundation of Korea. 2014:38-40.

40. Kaewta Suwannakarn. Biodiesel production from high free fatty acid content feedstocks thesis, Doctor of Philosophy Chemical Engineering, Clemson University. 2008:7.

41. Marmesat S, Macado RE, Velasco J, Dorbangarnes MC. Used frying fast and oil. Comparison of rapid test based on chemical and physical oil proprieties. Int J Sci Technol. 2007;42(60):1-8.

42. Sani J, Samir S, Rikoto II, Tambuwal AD, Sanda A, Maishanu SM, et al. Production and characterization of heterogeneous catalyst $(\mathrm{CaO})$ from snail shell for biodiesel production using waste cooking oil. Innov Energy Res. 2017;6(2):41-4.

43. Jacobson K, Gopinath R, Meher LC, Dalai AK. Solid acid catalyzed biodiesel production from waste cooking oil. Appl Catal B: Environ. 2008;85:86-91.

44. Allen C, Watts K. Comparative analysis of the atomization characteristics of fifteen biodiesel fuel type. 2000;43(2):207-211.

45. Sánchez N, Encinar JM, Martínez G, González JF. Biodiesel production from castor oil under subcritical methanol conditions. international journal of environmental science and development. 2015;6(1):61-66.

46. Sánchez N, Sánchez R, Encinar JM, González JF, Martínez G. Complete analysis of castor oil methanolysis to obtain biodiesel. Fuel. 2015;147:95-99.

47. Ajav EA, Akingbehin AO. A study of some fuel properties of local ethanol blended with diesel fuel. Agricultural Engineering International: CIGR J Scienti Res Develop. 2002:4.

48. Alamu OJ, Waheed MA, Jekayinfa SO. Alkali-catalysed laboratory production and testing of biodiesel fuel from Nigerian palm kernel oil. Agric Eng Int. 2007:9.

49. Van Gerpen J. Biodiesel processing and production. Fuel Process Technol. 2004;100:1-11.

50. Kapilan N, Ashok Babu TP, Reddy RP. Technical aspects of biodiesel and its oxidation stability. Int J Chem Tech Res. 2009;1(2):278-282.

51. Solomon WC, Kolade OA, Sa'ad A. Improving Jatropha biodiesel yield through the box-behnken process variables optimization method. Int J Eng Sci Res Technol. 2019;8(1):118-126.

52. Meher LC, Vidya Sagar D, Naik SN. Technical aspects of biodiesel production by transesterification-a review. Renew Sustain Energy Rev. 2004;10(3):248-268.

53. Alam M, Akram D, Sharmin E, Zafar F, Ahmad S. Vegetable oil based eco-friendly coating materials: A review article. Arabian J Chem. 2014;7(4):469-479.

54. Pinyaphong P, Sriburi P, Phutrakul S. Biodiesel fuel production by methanolysis of fish oil derived from the discarded parts of fish catalyzed by Carica Papaya Lipase. World Acad Sci Eng Technol. 2011;76:466-472.

55. Lesbani A, SusiY, Verawaty M, Mohadi R. Calcium oxide decomposed from chickens and goats bones as catalysts for converting discarded cooking oil to be biodiesel. Aceh Int J Sci Technol. 2015;4:7-13. 
56. Bouaid A, Martinez M, Jose A. Production of biodiesel from bioethanol and Brassica carinata oil: Oxidation stability study. Biores Technol. 2009;100(7):2234-2239.

57. Lee SL, Wong YC, Tan YP, Yew SY. Transesterification of palm oil to biodiesel by using waste obtuse horn shell-derived Cao catalyst. Energy Convers Manage. 2015;93:282-288.

58. Roschat W, Siritanon T, Yoosuk B, Promarak V. Energy Convers Manage. 2016;108:459-467.

59. Maneerung T, Kawi S, Dai Y, Wang CH. Sustainable biodiesel production via transesterification of waste cooking oil by using Cao catalysts prepared from chicken manure. Energy Convers Manage. 2016; 123:487-497.

60. Syazwani ON, Teo SH, Islam A, Taufiq-Yap YH. Transesterification activity and characterization of natural Cao derived from waste venus clam (Tapes belcheri S.) material for enhancement of biodiesel production. Process Safety Environ Prot. 2017;105:303-315.

61. Israa M, Rashid MA, Atiya BH, Hameed. Production of biodiesel from waste cooking oil using Cao-Egg shell waste derived heterogeneous catalyst. Int J Sci Res. 2015;6(11):94-103.
62. Wei Z, Xu C, Li B. Application of waste eggshell as low cost solid catalyst for biodiesel production. Bioresour Technol. 2009;100:2883-2885.

63. Hossain ABMS, Mazen MA. Effects of catalyst types and concentrations on biodiesel production from waste soybean oil biomass as renewable energy and environmental recycling process. Aus J Crop Sci. 2010:550-555.

64. Tang Y, Meng M, Zhang J, Lu Y. Efficient preparation of biodiesel from rapeseed oil over modified Cao. Appl Energy. 2011;88(8):2735-2739.

65. Girish N, Niju SP, Meera S, Begum KM, Anantharaman N. Utilization of a cost effective solid catalyst derived from natural white bivalve clam shell for transesterification of waste frying oil. Fuel. 2013;111:653-658.

66. Kappe CO. Controlled microwave heating in modern organic synthesis. Angew Chem Int. 2004;43:6250-6284.

67. Metaxas AC. Foundations of Electroheat. Wiley: New York, NY, USA. 1996.

68. Wong PK, Wong KI, Wong CM, Cheung CS. Modeling and optimization of biodiesel engine performance using kernel-based extreme learning machine and cuckoo search. Renew Energy. 2015;74:640-647. 